\title{
Rutschblock precision, technique variations and limitations
}

\author{
J. B. JAMIESON AND C. D. JOHNSTON \\ Department of Civil Engineering, University of Calgary, Calgary, Alberta T2N 1N4, Canada
}

\begin{abstract}
The Swiss rutschblock test provides practical information about the stability of snow slabs. However, its use by avalanche workers and ski guides is limited by the time required to perform the test and recommended minimum slope inclination $\left(30^{\circ}\right)$. The present study shows how time requirements can be reduced by cutting rutschblocks with cords or specialized saws - faster techniques that do not appear to affect the results. Comparing the rutschblock results with a stability index developed in Switzerland shows that the recommended minimum slope inclination can be reduced to $20^{\circ}$, provided a second person is present to observe the small block displacements associated with slope inclinations below $30^{\circ}$. Sets of rutschblocks on slopes that vary in inclination by $8^{\circ}$ or more are used to determine the effect of slope inclination on rutschblock scores. Also, the frequency distributions of six large sets of repeated tests are used to estimate the precision of one or two tests on a uniform slope.
\end{abstract}

\section{INTRODUCTION}

Slab avalanches begin with the shear failure of a weak snowpack layer (McClung, 1987) and the rutschblock was first used by the Swiss army in the 1960s (Föhn, 1987 a) to identify such critically weak snowpack layers. Föhn (1987a) proposed an interpretation of rutschblock scores in terms of slab stability for skiers, based on a comparison of rutschblock scores with nearby slab avalanching and with adjacent shear-frame stability indices.

In spite of the promise shown by the rutschblock test, its use was limited by the time each test required and by the recommended minimum slope inclination $\left(\geq 30^{\circ}\right)-$ which can compromise operator safety. During the winters of 1990-92 in the Cariboo and Monashee Mountains of western Canada, we investigated potentially faster methods of performing the rutschblock test and the effect of slope inclination on rutschblock scores. Also, we studied the natural variability of rutschblock scores on uniform slopes to determine the precision of one or two tests repeated on a particular slope.

\section{RUTSCHBLOCK TEGHNIQUE}

Test sites for rutschblocks should have an undisturbed snowpack that is representative of the avalanche terrain to be assessed and should be at least $5 \mathrm{~m}$ from trees to reduce the effect of inconsistent snow layering near trees.

A pit at least as deep as any potential failure planes, often 1-1.5 m deep, is excavated with a shovel (Fig. 1). The wall of the pit that faces down-slope is extended by shovelling until it is at least $2 \mathrm{~m}$ across the slope. The sides

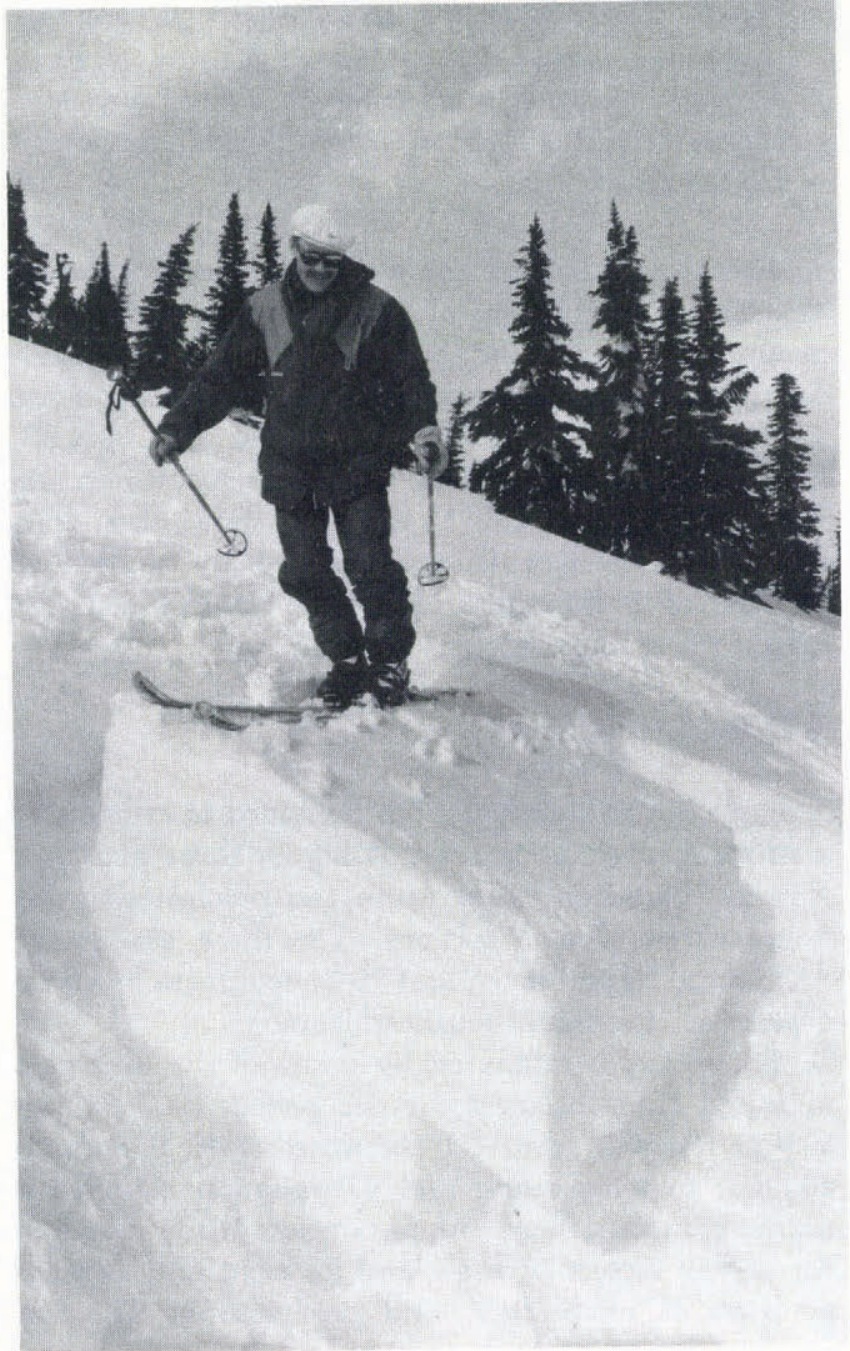

Fig. 1. Displaced rutschblock caused by skier loading. 


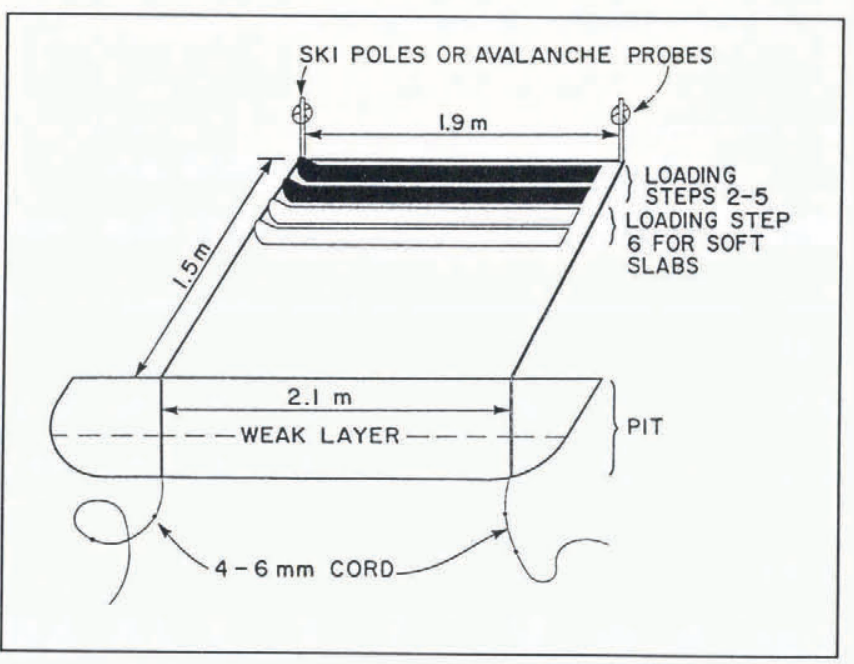

Fig. 2. Cord-cut rutschblock. Flaring the width of the block from 1.9 to $2.1 \mathrm{~m}$ is also used for other techniques that result in narrow side cuts such as saw-, pole- and skicut rutschblocks.

of the block can be either cut or shovelled, the latter method requiring more time. If the sides of the block are to be shovelled, then two $1.5 \mathrm{~m}$ long parallel marks extending up the slope from the pit wall and $2 \mathrm{~m}$ apart are made on the snow surface with a ski or ruler. After shovelling trenches just outside these marks, the upper wall is cut with the tail of a ski or a cord.

If the side walls are to be cut with a ski, ski pole, cord or saw, then the marks for the side walls are $2.1 \mathrm{~m}$ apart at the pit wall and $1.9 \mathrm{~m}$ apart at the up-slope end of the marks (Fig. 2). This flaring of the block reduces the potential for friction at the sides of the block that could affect the rutschblock score.

After the side walls are cut with a ski pole, saw or the tail of a ski, then the upper wall is cut by the same method. However, if a cord is used, then the side walls and upper wall can be cut simultaneously by extending the cord from the pit, up one side of the block dimensions, around ski poles or avalanche probes at the upper corners and down the other side to the pit (Fig. 2). Two operators in the pit, one holding either end of the cord, alternately pull their end of the cord to "saw" both side walls and the upper wall. An $8 \mathrm{~m}$ length of 4-6 mm cord with simple knots tied every $0.3 \mathrm{~m}$ successfully cut a wide variety of snow layers except for melt-freeze crusts of "knife" hardness (Colbeck and others, 1990). This cord-cutting technique produces a rectangular block unlike the method used for the "rutschkeil" test (Munter, 1991, p. 95-96) that produces a triangular block.

For the saw-cut rutschblocks, a $1.3 \mathrm{~m}$ long saw of $3.2 \mathrm{~mm}$ aluminum is used to cut the sides and upper wall while standing outside the dimensions of the block. The saw cuts a $10 \mathrm{~mm}$ gap in hard snow because of the offset teeth. Most of our saws were jointed so that the saws could be easily carried by skiers with backpacks.

\section{Loading steps and rutschblock scores}

Rutschblock scores range from 1 to 7 . A score of 1-6 corresponds to the loading step that produces a shear failure of the block. A score of 7 indicates that none of the six loading steps caused a shear failure. The following sequence of loading steps, except for the "soft slab" variation of step 6 , is similar to the steps described by Föhn (1987a):

1. The block slides during digging or cutting.

2. The skier approaches the block from above and gently steps down on to the upper part of the block (within $0.35 \mathrm{~m}$ of the upper wall).

3. Without lifting the heels, the skier drops from a straight leg to a bent-knee position, pushing downwards and compacting surface layers.

4. The skier jumps upwards clear of the snow surface and lands on the compacted spot.

5. The skier jumps again and lands on the same compacted spot.

6. For hard or deep slabs, the skier removes the skis and jumps on the same spot. For softer slabs where jumping without skis might penetrate through the slab, the skis are kept on, the skier steps down another $0.35 \mathrm{~m}$ - almost to mid-block - and pushes once then jumps three times.

7. None of the previous six loading steps produces a slope-parallel failure.

\section{Failure mode}

For rutschblock scores of 1,2 or 3 , and sometimes for higher scores, the entire block displaces in shear as shown in Figure 1 when the weak layer under the block fails. However, when the advanced loading steps that involve jumping are applied to softer slabs, the fracture often extends from the operator's skis down to the weak layer and along the weak layer to the pit, leaving a part of the block undisplaced.

\section{Interpretation of rutschblock scores}

Following three winters of field work involving over 900 rutschblock tests, we concur with Föhn's (1987a) interpretation of the results of tests performed in avalanche-starting zones: scores of 1,2 or 3 indicate that where snow conditions are similar to the test site, slab avalanches are likely to be triggered by skiers; scores of 4 or 5 indicate marginal stability - other meteorological and snowpack observations and tests must be used to assess "similar" slopes; and scores of 6 or 7 indicate a low (but not negligible) risk of skiers triggering avalanches on "similar" slopes.

The rutschblock is a useful slope test but it is not a one-step stability evaluation. The rutschblock test does not obviate snow profiles, field observations or other slope tests such as test skiing and explosive tests.

\section{NUMBER OF TESTS REQUIRED TO APPROX- IMATE MEDIAN RUTSCHBLOCK SCORE}

Avalanche workers and ski guides use slope tests such as rutschblocks, explosive tests and test skiing along with observations of avalanches, the snowpack and the weather to assess slab stability. When rutschblocks are 
used, typically only one or two tests are done to complement the information from other tests and observations.

To determine the number of tests required to approximate the median rutschblock score for a particular slope, we investigated the natural variability of rutschblock scores on uniform slopes. We selected sets of rutschblocks from the data collected during the winters of 1991 and 1992 based on the following criteria:

Each set consisted of more than 35 tests performed within $2-6 \mathrm{~h}$ on a single slope.

Each slope was free of rock outcrops and abrupt slope changes.

The failure plane (critical weak layer) was deeper than the operator's skis penetrated as a result of two jumps on the same spot.

Tests that varied by more than $4^{\circ}$ from the mean inclination for the slope (usually near the top and bottom of the slope) were excluded to minimize the effect of slope inclination on rutschblock scores (discussed later).

There were six sets that met these criteria and the distribution of rutschblock scores for these sets are summarized in Table 1 and shown in Figure 3.

Mean inclinations for the six sets ranged from $28^{\circ}$ to $33^{\circ}$. Within each set, tests were typically $0.3-0.5 \mathrm{~m}$ apart in the cross-slope direction and $1 \mathrm{~m}$ apart in the up-slope direction. Two of the six sets (6 March 1991 and 7 April 1992) involved two operators of similar weight and the other four sets involved only one operator.

Median rutschblock scores for the six slopes ranged from 3 to 5 . This range of median rutschblock scores is appropriate for two reasons. First, the frequency distributions for slopes with median rutschblock scores
Table 1. Frequency distributions of rutschblock scores
Incline $\left({ }^{\circ}\right)$
Rutschblock score

Date $\quad \mathcal{N}$ Min. Max. Min. Max. Med. Mean s.d.

1991

$\begin{array}{lllllllll}6 \text { Mar } & 36 & 25 & 30 & 1 & 5 & 3 & 2.97 & 0.74 \\ 6 \mathrm{Apr} & 43 & 27 & 34 & 3 & 4 & 4 & 3.67 & 0.47\end{array}$

1992

$\begin{array}{lllllllll}7 \text { Jan } & 49 & 30 & 37 & 3 & 6 & 4 & 3.94 & 0.48 \\ 3 \mathrm{Feb} & 45 & 27 & 35 & 3 & 7 & 5 & 5.11 & 0.89 \\ 31 \mathrm{Mar} & 37 & 28 & 36 & 4 & 7 & 5 & 4.89 & 0.80 \\ 7 \mathrm{Apr} & 67 & 27 & 35 & 4 & 6 & 4 & 4.16 & 0.41\end{array}$

of $1,2,6$ or 7 would be truncated by the limits of 1 and 7 that are inherent to rutschblock scores. Secondly, rutschblock precision is of greatest interest for scores in the 3-5 range, since slopes with a higher median score (6 or 7$)$ are generally stable and those slopes with a lower median score ( 1 or 2 ) are clearly unstable - safety prevented us from testing any slopes with a median score of 1 or 2 and a mean slope inclination of at least $28^{\circ}$.

The combined frequency distribution of the deviations from the median for the six sets of rutschblocks introduced in Table 1 and Figure 3 are shown in Figure 4. Since rutschblock scores are confined to the range $1-7$, a median of 3 does not permit a deviation of -3 and a median of 5 does not permit a deviation of +3 . Nevertheless, deviations of +3 were possible for four of

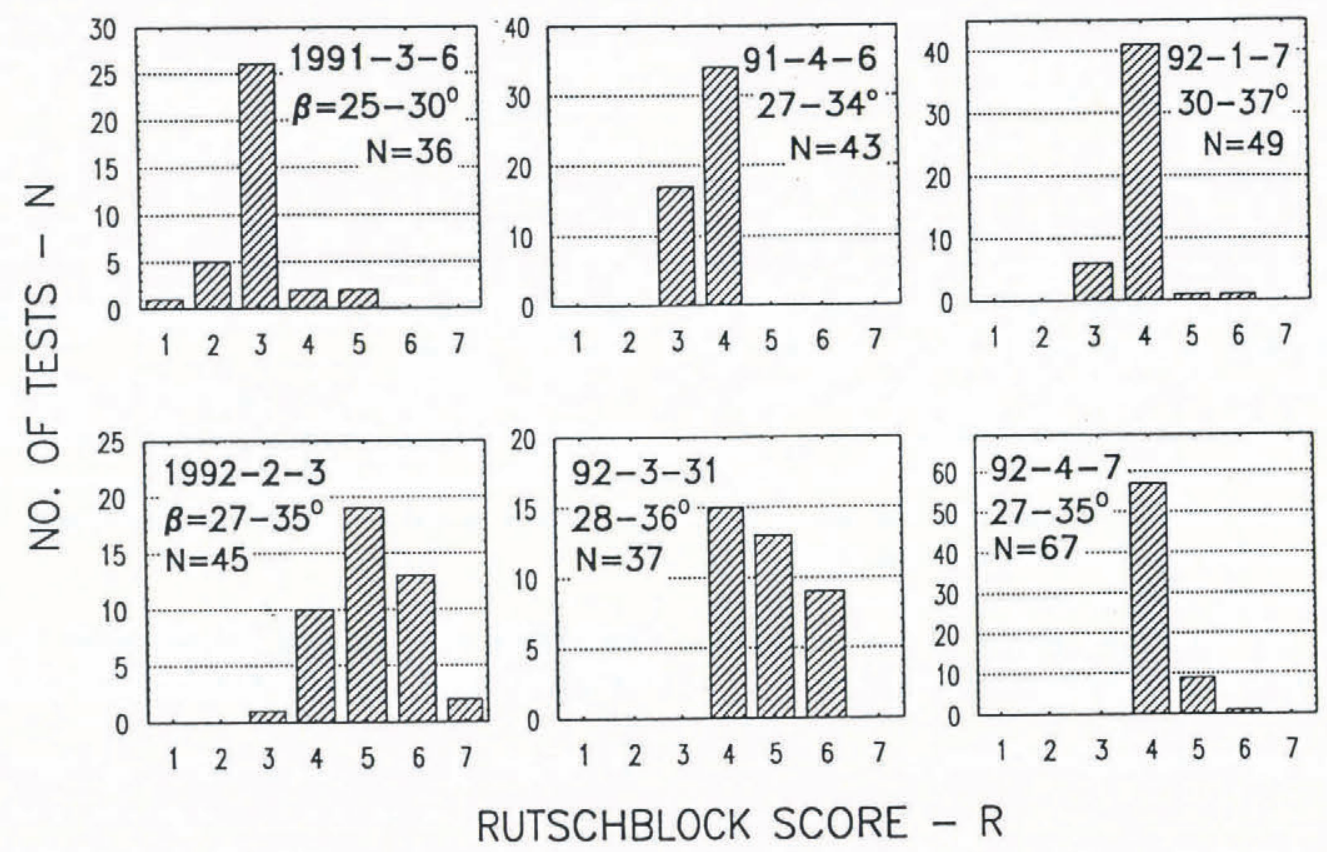

Fig. 3. Frequency distributions for six sets of rutschblock scores from uniform slopes. 


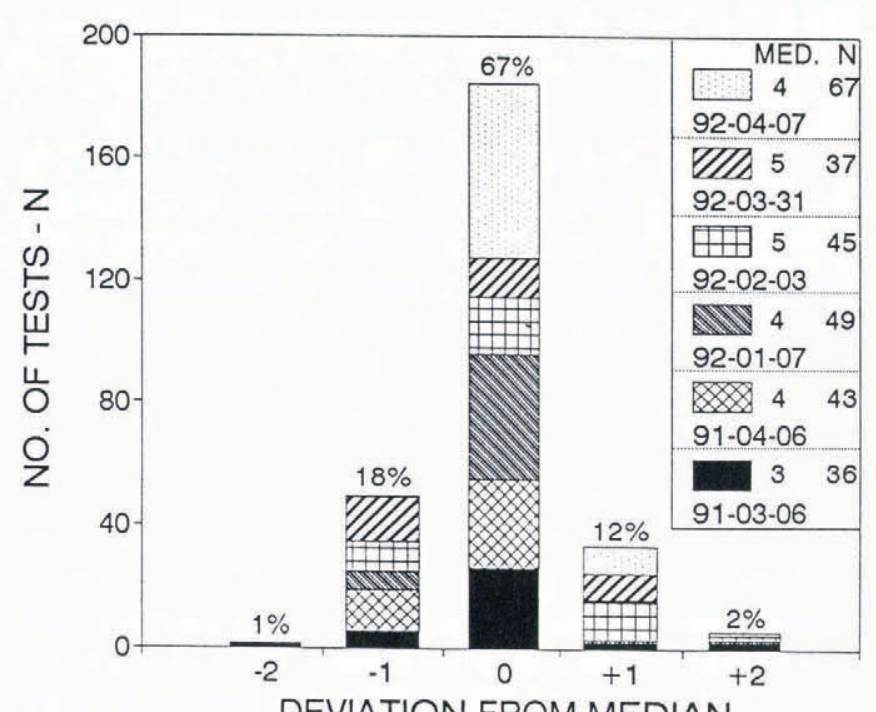

DEVIATION FROM MEDIAN

Fig. 4. Combined distribution of deviations from the median for the six sets of rutschblocks summarized in Table 1.

the six sets and deviations of -3 were possible for five of the six sets, but neither occurred in 277 tests. This indicates that, on uniform slopes, rutschblock scores that deviate by \pm 3 from the median are very rare. Indeed, only about $3 \%$ of the total results deviate from the median by more than \pm 1 as shown in Figure 4 .

By assuming the frequency distribution of the deviations shown in Figure 4 are representative of uniform slopes, the probability of a single rutschblock score or median of two scores being within one step of the slope median can be estimated. For the deviations of -2 , $-1,0,+1$ and +2 , the probabilities $P_{-2}, P_{-1}, P_{0}, P_{+1}$, $P_{+2}$ are $0.007,0.181,0.668,0.123$ and 0.022 , respectively. The probability of one test giving the median rutschblock score is approximately $P_{0}=0.67$. The probability of the result of one test being within one step of the slope median is

$$
P_{-1}+P_{0}+P_{+1}=0.97 \text {. }
$$

The probability of the median of two independent tests being within one-half step of the slope median is

$$
\begin{aligned}
P_{0} P_{0} & +2 P_{-1} P_{+1}+2 P_{-2} P_{+2}+2 P_{-2} P_{+1} \\
& +2 P_{-1} P_{0}+2 P_{-1} P_{+2}+2 P_{0} P_{+1}=0.91
\end{aligned}
$$

or being within one step of the slope median is 0.99 .

Although clusters of low or high rutschblock scores indicative of deficit or pinned areas (Conway and Abrahamson, 1984, 1988; Föhn, 1989) have not been reported in the literature, we believe that two independent tests should be more than $10 \mathrm{~m}$ apart to avoid the possibility of both tests being within a deficit or pinned area.

Although one or two tests appear to provide a useful estimate of the median for a uniform slope, greater variability, and hence reduced precision, is expected at sites that vary by more than $\pm 4^{\circ}$ from the mean slope inclination. In particular, we have observed increased variability of rutschblock scores near the top of a slope where wind action distributes snowfall unevenly and where changes in slope inclination can have considerable effect on absorbed solar radiation and consequently snow stratigraphy.

These approaches to the precision of one or two tests must be regarded with caution, since the stability of a snow slope may be more closely related to minimum rutschblock scores. Such minimum scores might indicate a weak zone or deficit area (Conway and Abrahamson, 1984; Föhn, 1989) capable of initiating slab failure.

\section{VARIATIONS OF RUTSCHBLOCK TECHNIQUE}

Föhn (1987a) reported that 20-30 min were required to prepare a rutschblock $1-1.5 \mathrm{~m}$ deep by shovelling the lower wall and both sides before cutting the upper wall with a cord. We evaluated two faster techniques in which the sides and upper wall are cut with a cord or a $1.3 \mathrm{~m}$ long saw.

The relatively narrow gaps $(4-10 \mathrm{~mm})$ on both sides of a block that is cut by cords or saws could possibly result in higher scores because of friction or rapid bonding caused by snow falling into the gaps. For this reason, we used slightly trapezoidal rutschblocks, approximately $1.9 \mathrm{~m}$ wide at the upper wall and $2.1 \mathrm{~m}$ wide at the lower wall (Fig. 2).

Average time requirements for two experienced operators to perform a 1-1.3 m deep rutschblock test for various methods of isolating the block are given in Table 2. These times include marking out the block on the surface of the snow, isolating and testing the block but not

Table 2. Time required for two persons for various rutschblock techniques

\begin{tabular}{cccccc}
\hline \multicolumn{3}{c}{ Tool used to cut } & \multicolumn{2}{c}{ Number of } & Average \\
Lower & Side & Upper & tests & timed tests & time \\
wall & walls & wall & & &
\end{tabular}

$\min$.

$\begin{array}{lccrrr}\text { Shovel } & \text { Shovel } & \text { Cord/ski } & 41 & 11 & 10.4 \\ \text { Shovel } & \text { Cord } & \text { Cord } & 81 & 30 & 9.1 \\ \text { Shovel } & \text { Ski } & \text { Ski } & 25 & 11 & 5.0 \\ \text { Shovel } & \text { Saw } & \text { Saw } & 796 & 283 & 4.6\end{array}$

selecting the site, preparing equipment or making observations of the slab or weak layer. Saw-cut rutschblocks required approximately half as much time as shovelled or cord-cut rutschblocks but saw-cut rutschblocks dictate that a saw weighing $1.2-1.8 \mathrm{~kg}$ be carried to the test slope.

Although ski-cut rutschblocks can be done without specialized equipment and almost as quickly as saw-cut rutschblocks, their usefulness is limited by the depth of cut that is practical. In hard snow, the bindings for the ski- 
boots limit the depth of cut and hence the effective depth of the test, to approximately $0.6 \mathrm{~m}$. Also, melt-freeze crusts are difficult to cut with a ski.

To investigate a possible effect of the narrow side gaps on rutschblock scores, six saw-cut rutschblocks and 15 cord-cut rutschblocks were each paired with the closest shovelled rutschblock - usually less than $3 \mathrm{~m}$ away that failed on the same weak layer on the same slope. Matching tests were usually completed with $1-2 \mathrm{~h}$ of each other.

There was no average difference between the saw-cut tests and their matching shovelled tests (Table 3). Differences between cord-cut tests and their matching shovelled tests averaged 0.5 rutschblock steps. Using a $t$ test for normally distributed data and a Wilcoxon test that requires only ordinal data, the difference in scores between matched tests is not significant at the $90 \%$ level as shown in Table 3 . Hence, we were unable to separate any effect of side friction due to saw- or cord-cutting from natural variability of rutschblock scores.

Table 3. Effect of narrow side cuts on rutschblock score

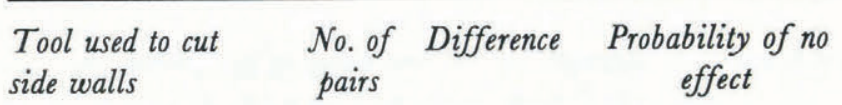

Mean s.d. Wilcoxon t-test

\begin{tabular}{lccccc}
\hline Saw vs shovel & 6 & 0.0 & 0.6 & - & 1.0 \\
Cord vs shovel & 15 & 0.5 & 1.2 & 0.17 & 0.15 \\
$\begin{array}{l}\text { Saw or cord vs } \\
\text { shovel }\end{array}$ & 21 & 0.3 & 1.0 & 0.20 & 0.17 \\
\hline
\end{tabular}

\section{MINIMUM SLOPE INCLINATION FOR RUTSCHBLOCKS}

Föhn (1987a) recommended slopes of at least $30^{\circ}$ for rutschblocks which requires that the test be done on inclinations steep enough to produce avalanches. Since dry-slab avalanches are quite rare on slopes of less than $30^{\circ}$ and very rare on slopes of less than $25^{\circ}$, we performed rutschblocks on slopes of less than $30^{\circ}$ to determine a minimum slope inclination. Our study of the minimum slope inclination for rutschblocks, and of the effect of slope inclination on rutschblock score, requires a shear-frame stability index that we denote by $S_{\mathrm{S}}$. The following derivation of $S_{\mathrm{S}}$ follows that of Föhn (1987b).

Slab failure is believed to begin when the shear strength of a buried weak layer $\Sigma_{\mathrm{s}}$ is less than the slopeparallel shear stress $\sigma_{x z}$ in the buried weak layer due to the weight of the overlying slab. (The slope-parallel and slope-perpendicular axes are denoted by $x$ and $z$, respectively.) Accordingly, Roch (1966a) used the ratio of $\Sigma_{8}$ to $\sigma_{x z}$ as a stability index for natural avalanches

$$
S=\Sigma_{\mathrm{s}} / \sigma_{x z} .
$$

From statics, the shear stress $\sigma_{x z}$ due to the overlying slab of mean density $\rho$ and thickness (measured vertically) $h$ on a slope of angle $\beta$ from the horizontal is $\rho g h \sin \beta \cos \beta$ in which $g$ is the acceleration due to gravity.

The shear strength of a large area is less than that obtained using a small shear frame, because of the greater probability of a weakness or flaw within the larger area. Accordingly, Föhn (1987b) modified Equation (1) by replacing $\Sigma_{\mathrm{s}}$ by the reduced strength of a large area $\left(>1 \mathrm{~m}^{2}\right)$ denoted here by $\Sigma_{\infty}$. For the $0.025 \mathrm{~m}^{2}$ frames that we used, the size effect is given by $\Sigma_{\infty}=0.65 \Sigma_{\mathrm{s}}$ (Sommerfeld, 1980; Föhn, 1987b).

Shear strength corrected for normal load is $\Sigma_{\infty}+\sigma_{z z} \tan \phi$ where $\sigma_{z z}=\rho g h \cos ^{2} \beta$ is the normal load and $\phi$ is the angle of "internal friction". However, Mellor (1975) questioned the merit of the correction and Roch's (1966b) empirical corrections are dependent on the type of snow grains. Nevertheless, an increase in shear strength - as measured by a shear frame - with normal load has been reported by Roch (1966b) and Perla and Beck (1983). Consistent with Föhn (1987b) and Roch (1966a), we use Roch's (1966b) empirical correction for granular snow given by $\tan \phi=0.4+0.08 \Sigma_{\infty}$ where $\Sigma_{\infty}$ is in $\mathrm{kPa}$.

To allow for the stress due to an artificial trigger such as a climber, skier, Snowcat or explosive, Föhn (1987b) added an incremental stress term $\Delta \sigma_{x z}$ in the denominator of Equation (1). For a hypothetical skier, the stability index is

$$
S_{\mathrm{S}}=\frac{\Sigma_{\infty}+\sigma_{z z} \tan \phi}{\sigma_{x z}+\Delta \sigma_{x z}} .
$$

For a hypothetical skier on a $30^{\circ}$ slope, Föhn's (1987b) formula for $\Delta \sigma_{x z}$ simplifies to $0.13 / h \mathrm{kPa}$ where $h$ is in $\mathrm{m}$. Since the derivation assumes snow is a linear elastic isotropic medium and neglects dynamic effects and ski penetration, the expression for $\Delta \sigma_{x z}$ only provides an order-of-magnitude estimation for the incremental shear stress due to a skier.

Föhn's (1987b) data suggest that slopes are often unstable for skiers when $S_{\mathrm{S}} \leq 1$, marginally stable when $1<S_{\mathrm{S}} \leq 1.5$ and usually stable when $S_{\mathrm{S}}>1.5$.

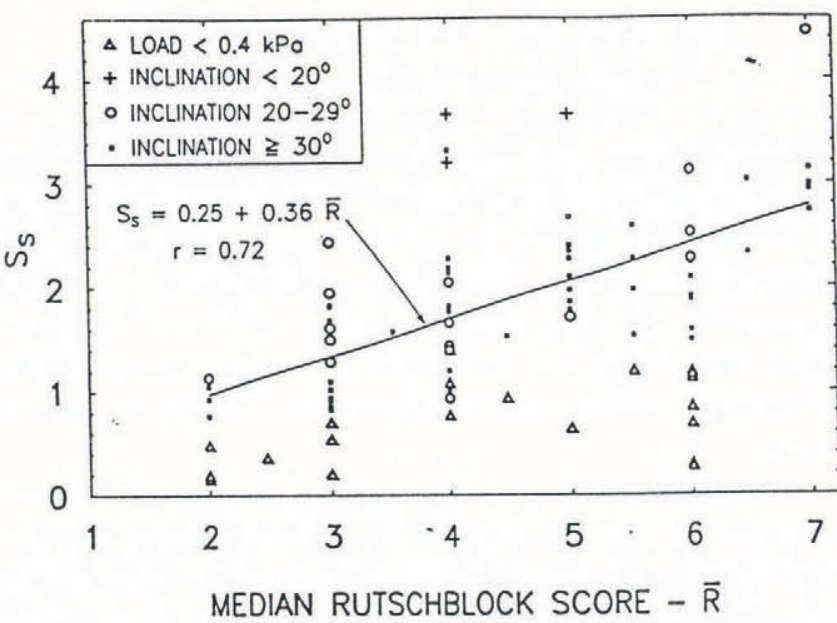

Fig. 5. Relation between $S_{\mathrm{S}}$ and median rutschblock score. Rutschblock tests for which the load $\rho g h<0.4 \mathrm{kPa}$ are not valid because the operator's skis often penetrate through or almost through, the slab. 
In Figure 5, values of $S_{\mathrm{S}}$ are plotted against median rutschblock scores obtained for the same weak layer from rutschblock tests made within $3 \mathrm{~m}$ of the shear-frame tests on the same day.

On slopes where the slab load $\rho g h$ was less than $0.4 \mathrm{kPa}$, most values of $S_{\mathrm{S}}$ are lower than values corresponding to $\rho g h \geq 0.4 \mathrm{kPa}$ and show less correlation with median rutschblock scores. For the soft slabs common in our study area, the operator's skis penetrate close to $(<50 \mathrm{~mm})$, or through, the weak layer being tested when $\rho g h<0.4 \mathrm{kPa}$. Hence, rutschblocks give inconsistent or high scores when the skis penetrate close to, or through, the weak layer being tested.

The data presented in Figure 5 are based on slopes that ranged in inclination from $15^{\circ}$ to $42^{\circ}$. The three points that correspond to rutschblock tests done at sites inclined at $15-18^{\circ}$ are outliers which, given their values of $S_{\mathrm{S}}$, have surprisingly low rutschblock scores. We suspect that Equation (2), which is based on shear failure, may not be representative of the rutschblock failures that occur on such low-inclination slopes. Until there are more results for slopes of less than $20^{\circ}$, we prefer to use rutschblocks on such low inclination slopes only to find weak layers and not for evaluating slab stability.

In Figure 5, there are 72 points based on rutschblock tests for which $\beta \geq 20^{\circ}$ and $\rho g h \geq 0.4 \mathrm{kPa}$. Although Föhn (1987a) used a second-order regression equation to relate rutschblock scores to $S_{\mathrm{S}}$, we use a simple linear equation since the relationship is purely empirical and because the variability of the points in Figure 5 does not justify a higher-order regression equation. The regression equation between $S_{\mathrm{S}}$ and the median rutschblock score

$$
S_{\mathrm{S}}=0.25+0.36 \bar{R}
$$

has a correlation coefficient of $r=0.74$ (significance level 0.99) .

Except for a median rutschblock score of 6, each of these mean values of $S_{\mathrm{S}}$ shown in Figure 5 is greater than the mean value for the lower rutschblock scores. This anomaly is not surprising, since all the points for $R=6$ are based on the "soft-slab" variation of the sixth loading step, which involves repeated jumping on the same compacted spot. (The "hard-slab" variation - jumping without skis - was not suitable in our study area, since it allowed the operator's boots to penetrate completely through many of the slabs we tested.) While the soft-slab variation of the sixth loading step may not generate more shear stress than the fifth step, it is possible that $R=6$ may indicate greater stability than $R=5$, because $R=6$ indicates that the block did not fail at the fifth loading step and because it is unclear whether $S_{\mathrm{S}}$ or $R$ is a better indicator of slab stability. Nevertheless, the soft-slab variation of the sixth loading step is not ideal, since it apparently does not cause more shear stress than the fifth step.

\section{EFFEGT OF SLOPE INCLINATION ON RUTSCH- BLOCK SCORE}

To study the effect of slope inclination on rutschblock scores, we selected 24 sets of four or more rutschblocks from data collected during the winters of 1991 and 1992 based on the following criteria:
Each set consisted of four or more tests performed within $2-6 \mathrm{~h}$ on a single slope.

Slope inclinations within each set varied by at least $8^{\circ}$.

Each rutschblock in a set slid on the same snow layer.

An example of such a set is shown in Figure 6. For the 27 tests, the slope inclination varied from $15^{\circ}$ to $44^{\circ}$ and the rutschblock scores varied from 2 to 6 . In spite of the variability shown in Figure 6, there is a general trend for rutschblock scores to increase as slope inclination decreases.

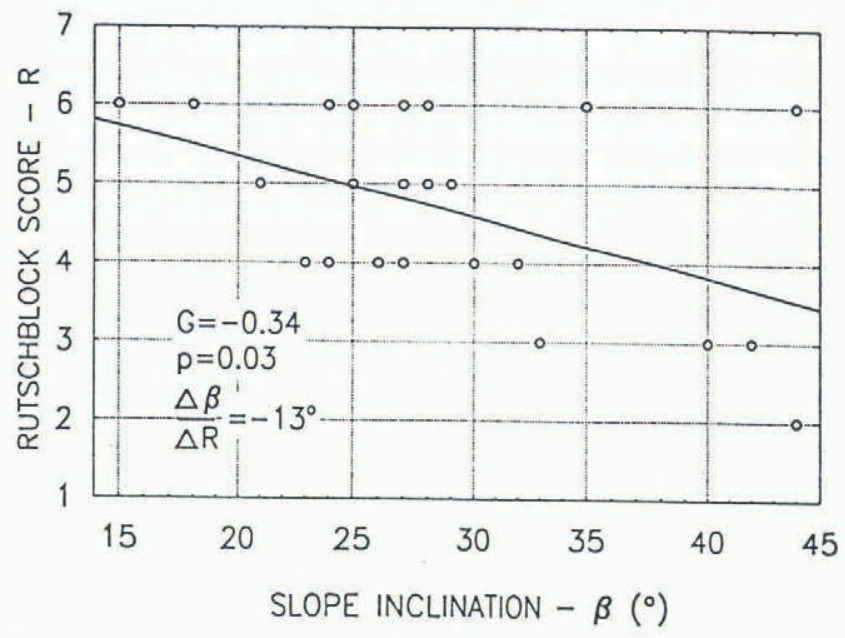

Fig. 6. Rutschblock scores for 27 rutschblock tests completed on a 16-44 slope on 13 March 1991. In spite of considerable variability, these data show a tendency for rutschblock scores to increase for a decrease in slope inclination.

The effect of slope inclination $\beta$ on rutschblock score $R$ is assessed in terms of $\Delta \beta / \Delta R$, which is the reciprocal of the slope of a straight line fitted to the data by least squares. For any given set of rutschblock scores from a particular slope, $\Delta \beta / \Delta R$ is the average change in slope inclination associated with a one-step increase in rutschblock score.

The correlation between $R$ and $\beta$ is assessed with the gamma correlation from non-parametric statistics that is suited to rutschblock scores which are ordinal and often involve ties (Siegel and Castellan, 1988, p. 291). For the data shown in Figure 6, the gamma correlation coefficient is $G=-0.34$ and there is only a $3 \%$ probability $(p=0.03)$ of getting such a correlation from sampling random data.

For each of the 24 sets of four or more rutschblocks on slopes that varied by at least $8^{\circ}$, the probabilities associated with the correlations are plotted along the abscissa of Figure 7. A separate symbol is used for the 11 sets that involve less than ten tests, since for such small sets the value of $p$ is only a rough estimate (Statsoft, 1991, p. 270). For most sets, $p>0.10$, indicating that slope inclination had no significant effect on rutschblock scores. There are three sets for which the gamma 


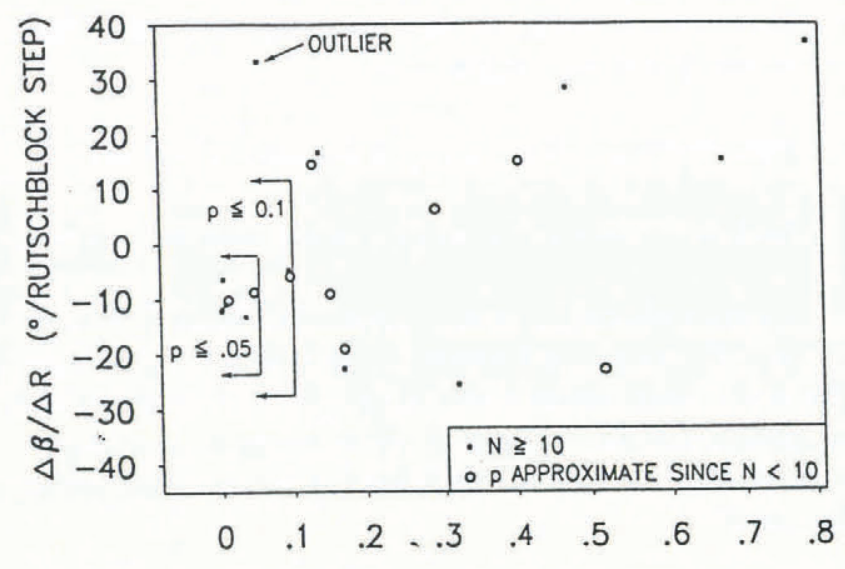

PROBABILITY OF GAMMA CORRELATION - $p$

Fig. 7. Probabilities associated with gamma correlations between rutschblock score $R$ and slope inclination $\beta$. Each point represents four or more tests on a particular slope which ranged in inclination by at least $8^{\circ}$. Ten of the 11 points for which $p<0.1$ show a one-step increase in rutschblock score for a 5-13 decrease in slope inclination.

correlation between $R$ and $\beta$ is marginally significant $(0.05<p<0.10)$ and seven more significant sets $(p \leq 0.05)$. Therefore, 14 of the 24 sets do not exhibit a significant $R-\beta$ effect.

The ordinate of Figure 7 shows $\Delta \beta / \Delta R$. None of the significant sets $(p \leq 0.05)$ and only one marginally significant set $\left(p=0.05, \Delta \beta / \Delta R=33^{\circ} /\right.$ rutschblock step) have a positive value for $\Delta \beta / \Delta R$. For this point, $\Delta \beta / \Delta R$ is 2.8 standard deviations from the average value for ten tests for which $p \leq 0.10$. This makes it an outlier according to the modified $3 \sigma$ test (Lipson and Sheth, 1973 , p. 91 ). For the three other sets of marginal significance and for all seven of the significant sets, $\Delta \beta / \Delta R$ ranges from $-13^{\circ}$ to $-5^{\circ}$ per rutschblock step and averages $-9.7^{\circ}$ per rutschblock step. Such values indicate that the rutschblock score tended to increase by 1 when the slope inclination decreased by approximately $10^{\circ}$. The relations between $R$ and $\beta$ for the 11 sets for which $p \leq 0.10$, including the outlier, are shown in Figure 8.

An alternative to analyzing the effect of slope inclination based on field measurements (Figs 6, 7 and 8 ) is an approach based on Equation (3) and on the calculated stresses in Equation (2). Equation (3) provides values of $S_{\mathrm{S}}$ that correspond to median rutschblock scores and the terms $\sigma_{z z}, \sigma_{x z}$ and $\Delta \sigma_{x z}$ in Equation (2) all include slope inclination $\beta$ which can be adjusted by trial and error to obtain $\Delta R=1$. However, this approach requires typical values for $\rho$ and $\Sigma_{8}$ in Equation (2). We use $\rho=200 \mathrm{~kg} \mathrm{~m}^{-3}$ and $\Sigma_{\mathrm{s}}=1.5 \rho \mathrm{gh}$, where the latter represents an approximate upper limit for shear strength of weak layers on slopes capable of producing natural slab avalanches (Schleiss and Schleiss, 1970; Jamieson and Johnston, 1993).

Consider, for example, a rutschblock score of 3 on an inclination of $35^{\circ}$. To obtain $S_{\mathrm{S}}=1.34$ which corresponds to $R=3$ (Equation (3)) while satisfying Equation (2) and $\Sigma_{\mathrm{s}}=1.5 \rho g h$, the height of the slab $h$ must be $0.38 \mathrm{~m}$. Fixing this value of $h$ and hence $\Sigma_{\mathrm{s}}$, the value of $\beta$ in $\sigma_{z z}, \sigma_{x z}$, and $\Delta \sigma_{x z}$ of Equation (2) has to be adjusted to $23^{\circ}$ to obtain the value of $S_{\mathrm{S}}=1.70$ that corresponds to $R=4$. Calculated decreases in slope inclination from $35^{\circ}$ required to increase rutschblock scores by 1 are given in Table 4 for the 2-6 range of rutschblock scores for which Equation (3) is valid. The resulting values of $\Delta \beta / \Delta R$ range from $-16^{\circ}$ to $-6^{\circ}$ which agree well with the values determined from field measurements.

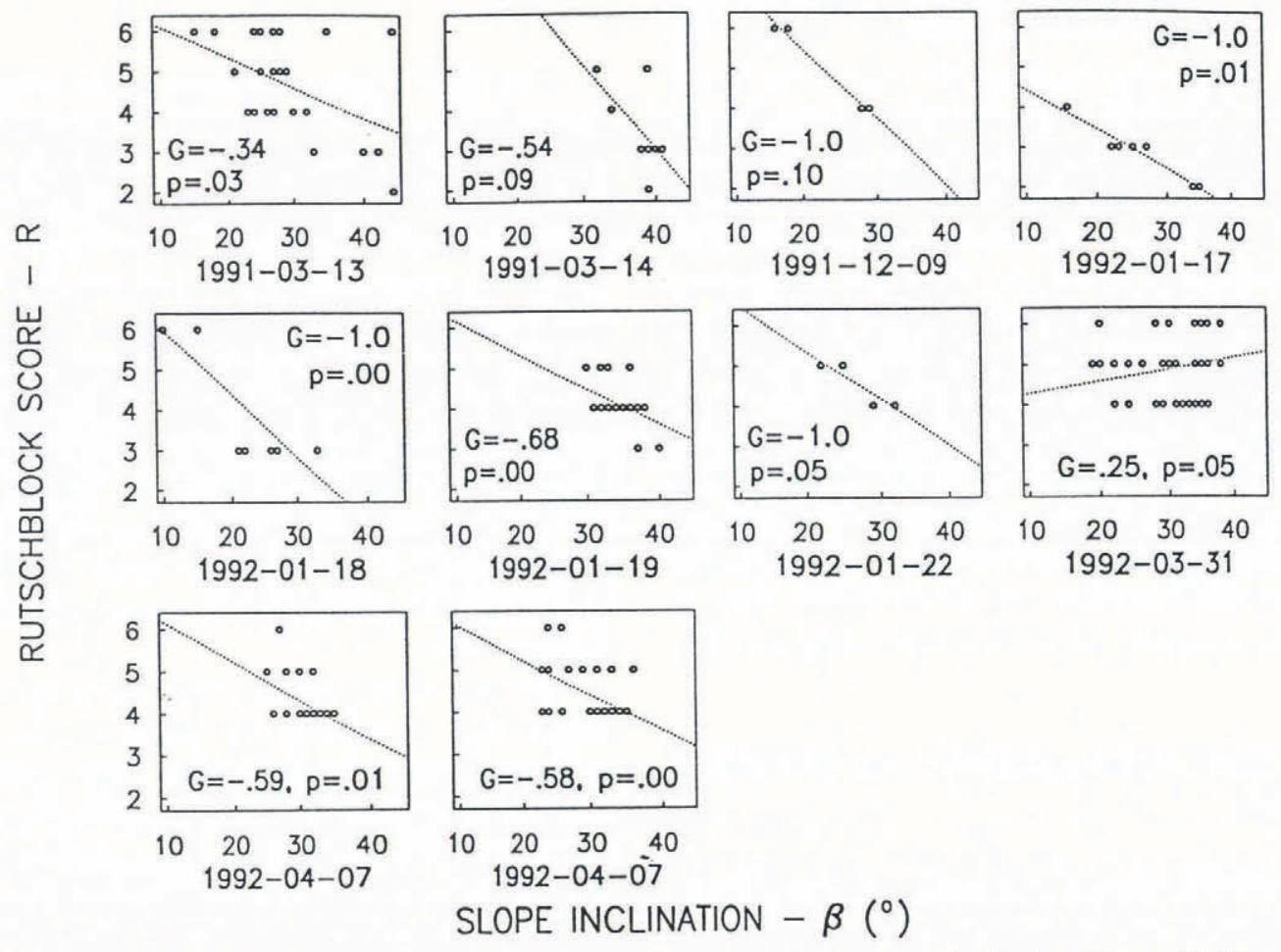

Fig. 8. Eleven sets of rutschblock tests which show significant $(p \leq 0.05)$ or marginally significant $(0.05<p<0.1)$ slope effects based on gamma correlations between rutschblock score and slope inclination. 
Table 4. Calculation steps for effect of slope inclination on rutschblock score

Rutschblock score on a $35^{\circ}$ incline

$\begin{array}{lllll}2 & 3 & 4 & 5 & 6\end{array}$

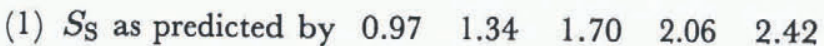
Equation (3)

(2) Slab height $(\mathrm{m})$

$\begin{array}{lllll}0.29 & 0.38 & 0.49 & 0.65 & 0.93\end{array}$

which satisfies

$\Sigma_{\mathrm{s}}=1.5 \rho g h$ and

Equation (2)

(3) $R$ for $\Delta R=1$

(4) $S_{\mathrm{S}}$ for $\Delta R=1$

$\begin{array}{lllll}3 & 4 & 5 & 6\end{array}$

(Equation (3))

$\begin{array}{lllll}1.34 & 1.70 & 2.06 & 2.42 & 2.78\end{array}$

(5) $\beta\left({ }^{\circ}\right)$ required by

$\begin{array}{lllll}19 & 23 & 26 & 28 & 29\end{array}$

Equation (2) for

line 4

(6) Change in slope $\quad \begin{array}{lllll}-16 & -12 & -9 & -7 & -6\end{array}$ angle (line $5-35^{\circ}$ )
For the dry-slab blocks in our study, basal friction appears to be critical on slopes of $25-30^{\circ}$. Occasionally, slabs are reported to fail on slopes of $25-30^{\circ}$ but displace less than $0.5 \mathrm{~m}$ without releasing a slab avalanche (see photograph on p. 161 of Daffern (1992)). Also, in support of this critical range of inclinations, Perla (1977) reported that at most $5 \%$ of all slab avalanches start on slopes of $30^{\circ}$ or less and, at most, $1 \%$ of all slab avalanches start on slopes of $25^{\circ}$ or less.

Block displacements of less than $20 \mathrm{~mm}$ are sometimes not noticed by the skier loading the rutschblock. On slopes of less than $30^{\circ}$, rutschblock displacements were $20 \mathrm{~mm}$ or less for 118 of 287 tests $(41 \%)$. Failure to notice displacement can result in an incorrect rutschblock score and, at worst, an overestimation of slab stability. To ensure rutschblock failures are noticed on the earliest loading step, we recommend that the lower wall of the block be cut smoothly and that the displacement be observed by a second person standing near the lower wall, especially on slopes of $30^{\circ}$ or less.

\section{CONCLUSIONS}

The following are the main conclusions reached after three winters of field work involving over 900 rutschblock tests in the Cariboo and Monashee Mountains. During testing in the study areas, the snow was dry, the snowpack depth was rarely less than $2 \mathrm{~m}$ and the depth of the active weak layers was rarely more than $1 \mathrm{~m}$.

1. On a uniform slope that varies in slope inclination by less than $10^{\circ}$, one rutschblock test has an approximate $67 \%$ probability of giving the median score for the slope and $97 \%$ probability of giving a score within one step of the slope median. The probability of the median score of two independent tests being within one-half step of the slope median is approximately $91 \%$.

2. The time required to perform a rutschblock is reduced by approximately half by using a ski or specialized saw to cut the sides and upper wall of the rutschblock. Provided no knife-hard crusts exist in the slab to be cut, $4-6 \mathrm{~mm}$ knotted cords can also be used. These alternative block-cutting techniques do not appear to affect the resulting rutschblock scores.

3. The procedure for loading step 6 is not ideal. One method, jumping after removing the skis, did not effectively test most slabs in our study area because the operator's boots penetrated too deeply. It is doubtful that the alternative method, moving $0.35 \mathrm{~m}$ down the block to jump with skis on, effectively increases the incremental shear stress in the weak layer compared to loading step 5 .

4. The rutschblock test can give erroneously high scores when the operator's skis penetrate through, or close to $(<50 \mathrm{~mm})$, potential failure planes. Failure planes underlying a slab load of less than $0.4 \mathrm{kPa}$ are frequently not tested effectively by the rutschblock test.

5. Rutschblock scores from inclinations as low as $20^{\circ}$ correlate with the stability index for skier loading $S_{\mathrm{S}}$. Rutschblock scores on slopes below $20^{\circ}$ are not

Fig. 9. Effect of slope inclination on the percentage of rutschblocks arrested by basal friction. 
consistent with the same correlation. Until further studies on such gentle slopes are completed, rutschblock tests on such low-inclination slopes should be used only to locate potential failure planes.

6. There is a general tendency for rutschblock scores to increase by one step for each $10^{\circ}$ decrease in slope inclination. Such an effect is often obscured by natural variability of rutschblock scores and was only apparent in ten of 24 data sets.

7. Rutschblock tests done on slopes of less than $30^{\circ}$ require a smooth lower wall and a second person standing in or near the pit to observe the small displacements (less than $20 \mathrm{~mm}$ ) that indicate a shear failure.

\section{ACKNOWLEDGEMENTS}

We are grateful to the Natural Sciences and Engineering Research Council of Canada and Mike Wiegele Helicopter Skiing for financial support provided under the Research Partnerships Program, to P.A. Schaerer for technical advice during the field work, to P. M. B. Föhn of the Swiss Federal Institute for Snow and Avalanche Research and S. Kinne of Seattle for helpful comments during the preparation of this paper and to M. Shubin and $J$. Hughes for their care and perseverance in obtaining field measurements, often under difficult conditions.

\section{REFERENCES}

Colbeck, S. C. and 7 others. 1990. International classification for seasonal snow on the ground. Wallingford, Oxfordshire, International Association of Scientific Hydrology.

Conway, H. and J. Abrahamson. 1984. Snow stability index. F. Glaciol., 30(106), 321-327.

Conway, H. and J. Abrahamson. 1988. Snow-slope stability-a probabilistic approach. 7. Glaciol., 34(117), 170-177.

Daffern, T. 1992. Avalanche safety for skiers and climbers. Revised edition. Calgary, Rocky Mountain Books.
Föhn, P. M. B. 1987a. The "Rutschblock" as a practical tool for slope stability evaluation. International Association of Hydrological Sciences Publication 162 (Symposium at Davos 1986-Avalanche Formation, Movement and Effects), 223-228.

Föhn, P.M.B. 1987b. The stability index and various triggering mechanisms. International Association of Hydrological Sciences Publication 162 (Symposium at Davos 1986-Avalanche Formation, Movement and Effects), 195-211.

Föhn, P. M. B. 1989. Snowcover stability tests and the areal variability of snow strength. In Proceedings of the International Snow Science Workshop (Symposium at Whistler 1988). Revelstoke, Canada, Canadian Avalanche Association, 262-273.

Jamieson, J.B. and C.D. Johnston. 1993. Shear frame stability parameters for large-scale avalanche forecasting. Ann. Glaciol., 18, 268-273.

Lipson, C. and N.J. Sheth. 1973. Statistical design and analysis of engineering experiments. New York, McGraw-Hill.

McClung, D. M. 1987. Mechanics of snow slab failure from a geotechnical perspective. International Association of Hydrological Sciences Publication 162 (Symposium at Davos 1986-Avalanche Formation, Movement and Effects), 475-507.

Mellor, M. 1975. A review of basic snow mechanics. International Association of Hydrological Sciences Publication 114 (Symposium at Grindelwald 1974-Snow Mechanics), 251-291.

Munter, W. 1991. Neue Lawinenkunde, ein Leitfaden für die Praxis. Bern, Schweizer Alpen-Club.

Perla, R. 1977. Slab avalanche measurements. Can. Geotech. J., 14(2), 206-213.

Perla, R. and T.M.H. Beck. 1983. Experience with shear frames. J. Glaciol., 29(103), 485-491.

Roch, A. 1966a. Les déclenchements d'avalanche. International Association of Scientific Hydrology Publication 69 (Symposium at Davos 1965Scientific Aspects of Snow and Ice Avalanches), 182-195.

Roch, A. $1966 \mathrm{~b}$. Les variations de la résistance de la neige. International Association of Scientific Hydrology Publication 69 (Symposium at Davos 1965 - Scientific Aspects of Snow and Ice Avalanches), 86-99.

Schleiss, V.G. and W.E. Schleiss. 1970. Avalanche hazard evaluation and forecast, Rogers Pass, Glacier National Park. National Research Council of Canada. Associate Committee on Geotechnical Research. Technical Memorandum 98, 115-122.

Siegel, S. and N.J. Castellan, Jr. 1988. Nomparametric statistics for the behavioral sciences. New York, McGraw-Hill.

Sommerfeld, R. A. 1980. Statistical models of snow strength. F. Glaciol., 26(94), 217-223.

Statsoft. 1991. CSS: statistica. Tulsa, OK, Statsoft Inc.

The accuracy of references in the text and in this list is the responsibility of the authors, to whom queries should be addressed. 